\title{
Management Commitment to Strengthen The Quality Improvement of Regional Financial Report
}

\author{
Nurlinda Nurlinda ${ }^{1}$, Erlina Erlina ${ }^{2}$, Azhar Maksum ${ }^{3}$, Rina Bukit $^{4}$ \\ \{erlina@usu.ac.id ${ }^{1}$, nurlinda@polmed.ac.id ${ }^{2}$, azharmaksum16@gmail.com ${ }^{3}$ \} \\ 1,2,3,4 Universitas Sumatera Utara, Jalan Almamater Kampus USU Medan, Indonesia
}

\begin{abstract}
The purpose of this research was to test the role of management commitment in improving financial report quality. This research was quantitative-qualitative study used primary data sourced from the questionnaire on 47 samples. Data analysis used multiple linear regression. The results showed that the implementation of internal control systems had significant positive effect on the quality of financial statements, while the implementation of accounting standards had no effect on the quality of financial statements and management commitments were not strengthening the implementation of internal control systems and the implementation of accounting standards on the quality of financial statements of government sector.
\end{abstract}

Keywords: Regional head commitment, internal control system, accounting standards, financial report quality.

\section{Introduction}

The report of test results from year to year in the government sector is increasingly showing an improvement in the quality of adequate financial statements. The indicators that can be used to declare quality and free financial statements from material miss management can be carried out using an independent third party to conduct the press. Opinions obtained from the examination can be used to measure the quality of financial report [1]. According the Law No.15, 2004 The opinion obtained is a professional statement as a conclusion on the examination of the level of fairness of information presented in the financial statements of local government (Pemda) [2]. The opinions given by are based on (1) Compliance with Government Accounting Standard (SAP), (2) Adequacy of disclosure (adequate disclosure), (3) compliance with statutory regulations and (4) Effectiveness of Internal Control System (SPI) [3].

Year 2018 RI submitting the summary of the Semester examination results (IHPS) to the House of Representatives Semester 1 year 2018. The reported IHPS showed that the findings of 15,733 problems worth Rp. $11.55 \mathrm{~T}$, the journey of civil servants still inflicted losses of up to $22.33 \mathrm{M}$, OJK is called the tax owed Rp. $901.1 \mathrm{M}$, there is still a ministry for opinion disclimer ( www.merdeka.com). In addition, found 7,539 problems in the internal control system (SPI) weakness and the disobedience of regulation and the law. IHPS I Year 2018 also contains monitoring results follow-up recommendation results (TLHP) up to year 2018 of LHP published year 2005-30 June 2018. Cumulatively, until 30 June 2018, CPC recommendation of the examination results of the period 2005-30 June 2018 has been followed up by the entity with the delivery of assets and/or deposits of money to the state or local treasury or the company is $\mathrm{Rp} 79.98$ trillion. The high value of depositing money to the state Treasury shows that the financial statements produced are not maximal even though in 2018 from 88 opinions 80 The lawyers have a reasonable opinion without exception. 


\section{Review of Literature}

Paton (1970) considers the entity theory to be "an organization deemed to be an independent entity or an economic entity, acting on its own behalf, and its position separate from the owner or other party that invested funds in Organization " [4]. Thus the economic entity is certainly the center of attention or accounting object. Fogarty \& Kalbers (1993) mentions that each business entity conducts activities to meet the needs of various stakeholders [5]. If related to the preparation of financial statements, then the application of this theory has been implemented, proved the term of the reporting entity contained in the explanation of Article 51 paragraph (2) and paragraph (3) of law (ACT) No. 1 year 2004 on the Treasury Country. The law states that "each Ministry of state/institution is a reporting entity that is not only obliged to conduct accounting, but also obliged to submit the responsible of financial reporting.

\section{a. Quality Financial Report}

Financial reporting is the process of drafting and presenting the regional government's financial statements by the reporting entity as a result of a consolidation of the SKPD financial statement as the accounting entity [6]. Indicators determine the quality of financial statements can be seen from qualitative characteristics. Qualitative character is a normative measure in order to meet normative prerequisites for financial statements to be declared quality [7] Charakter of qualitative must be met with financial statements to make quality consist of relevant, reliable, comparable, intelligible [8] [9][10].

\section{b. Internal Control System}

Referring to PP number 60 year 2008, internal control is an "integral process of action and activities undertaken continuously by the leadership and all employees to provide adequate confidence to achieve the objectives of the Organization through Effective and efficient activities, reliability of financial reporting, safeguarding of state assets and compliance with regulations " [11]. Internal control is an "executive-run process (consisting of regional heads/agencies/departments and all personnel) designed to provide adequate confidence in the achievement of three objectives consisting of, reliability Financial statements, compliance with applicable laws and regulations, effectiveness and efficiency of operations "(Bastian, 2006). Elements of internal control system in regulation of the Republic of Indonesia number 60 year 2008 include: "a) control environment; b) risk assessment; c) control activities; d) Information and communication; e) Monitoring ". The results found significant influence of internal control system to the quality of financial report [12][13][14]. The findings show that the better the implementation of internal controls will be the better quality of the resulting financial statements.

\section{c. Government Accounting Standards}

The results of RI's examination find non-compliance with the provisions of the legislation resulting in regional losses, regional loss potential, lack of acceptance, administrative weakness, inadequation, and imeffectiveness. These disobedience are not yet applied to the maximum relevant accounting standards. State financial management is guided by government regulation No. 71 year 2010 on accrual-based government accounting standards. The indicators used are 8 principles of accounting and financial reporting consisting of, "1) accounting bases; 2) historical value; 3) Realization; 4) subctance to the formal form; 
5) Reality; 6) Consistency; 7) Disclosure; 8) Reasonable presentation. The results showed there was a positive and significant influence on the implementation of accounting standards for the quality of financial report [15][16][1][17][18]. Referring to the results of this research can be concluded that the preparation of financial statements compiled in accordance with accounting standards will improve the quality of the financial statements.

\section{d. Management Commitments}

Referring the law No. 60 that the internal control system is a continuous action from the principal to give adequate assurance to the reliability of financial reporting shows that as good as any standards used and as good as any Systems that are implemented without a good management commitment will not be adequate in generating quality financial statements [19]). Organizational commitment theory is the basis of management commitments. Staw (1977); Salancik \& Pfeffer (1977) divides commitments in two forms of commitment, consisting of attitude commitments (attitudinal commitment) and behavioral commitment commitments [20]. Commitment is an agreement or attachment to doing something best in a particular organization or group [21]. In this research the management commitment is the commitment of regional head of office at the follow-up of the recommendation results [22]. Referring to the Law No. 15 of 2004 concerning management check and the State financial responsibility of article 20 states that "Officers must follow up recommendations in the report of the test results; Officials shall provide an answer to the CPC explanation about follow-up recommendations in the examination results report; Answer or explanation is given to the no later than 60 (sixty) days after the report of the test results received; monitors the follow-up of the test result " [2]. The obligation of regional head is further emphasized with the validity of government regulation No. 12 year 2019 on regional finance management [6]. Pursuant to PP number 12 (2019) of Article 192, said that "the regional head gave a response and made adjustments to the report of the Financial Audit Agency's examination of the local government's financial statements" [6]. The known officers do not carry out the obligations referred to in paragraph (1) may be subject to administrative sanctions in accordance with the provisions of legislation in the field of personnel and/or criminal sanctions.

Commitment to the leadership to be the determinant of the other elements of control system [19], thus the commitment to moderate the quality of financial statements [23]. The result found that there was a positive influence on regional head commitments on the quality of financial statements. The SAP implementation to improve the quality of financial statements will succeed when management has a high commitment [22][24][25]. This commitment shows that the management works more professionally to produce quality financial statements [26]. The results of the research found that the leadership commitments influence the implementation of accounting standards [27].

\section{Research Methodology}

This research is quantitative - qualitative research. The research Data is obtained by collecting questionnaire where the respondent is one of the Ministries of the Republic of Indonesia. The sample consists of 47 respondents who are financial managers. The questionnaire contained a statement that was weighted with a valuation of 1-5 by using a Likert scale. Data processing using Smart PLS version 3.0. 


\section{Results And Discussion}

The application of internal control system, implementation of accounting standards, management commitments, has a positive coefficient value. This can be interpreted if there is an increase of the independent variable, it will further increase its dependencies variable. It can therefore be concluded that if the application of internal control system, the implementation of accounting standards and management commitments are increasing, it will increase the quality of financial statements. However, for moderating variables shows that management commitments only positively impact the implementation of internal control systems while in the application of negative influential accounting standards. The value of $R$ Square on the moderation model indicates a value of 0,473 . This value indicates that the influence of the internal control system implementation variables, the implementation of accounting standards, the management commitments, affects the quality of the financial statements by $47.3 \%$, while the remaining $52.7 \%$ is affected by variables Outside of this model.

\subsubsection{The Internal control system implementation affects the quality of financial statements.}

The internal control system implementation variables affect the quality of financial statements. The test result indicates that the internal control system (X1) has a T-statistic value of 2,365 where this value is above 1.96. It can thus be concluded that the implementation of internal control systems positively affects the quality of financial statements. In the end, the main problem is human resource related (SDM). The interview found that SDM still does not have adequate skills as well as lack of training and technical guidance. Besides, the frequent entry of staff also becomes a problem in the implementation of internal control system. The results of this study supported the research results of [12][13][14] who found there was an influence on the implementation of the control system on the quality of financial statements.

\subsubsection{The accounting standard implementation affects the quality of financial statements.}

The Government Accounting Standard implementation variable (X2) has a t-statistics value of 1,532, where its value is below 1.96 and the line coefficient is positively valued, thus it can be concluded that the independent variable implementation of accounting standards Has no effect on the quality dependent variables of the financial statements. Issues related to human resources competency in managing financial into own problems within the organization. Changing staff in managing finances too often raises problems in the mastery of the work considering the lack of training frequency and technical guidance is less given. Based on the results of the study also showed that the recent background of education owned by staff who manage the financial activities are not overall educated accounting. 17 respondents from 47 respondents found uneducated accounting. Insufficient high-educated staff accounting led to a lack of understanding of the relevant accounting comprehension in managing financial statements. The results of this study were not in accordance with the research who found there was an influence on the implementation of accounting standards for the quality of financial statements [15][1][17][18].

\subsubsection{Variable management commitments affect the quality of financial statements.}

The Management commitment variable (X3) has a t-statistics value of 0.975 , where the value is below 1.96 and the line coefficient is positive value, so it can be concluded that the management commitment has no effect on the quality variables Financial statements. Issues 
related to human resources competency in managing financial into own problems within the organization. The interview found that human resource (SDM) still does not have adequate skills as well as lack of training and technical guidance. Besides, the frequent entry of staff also becomes a problem in the implementation of internal control system. In the end when management is not or less committed as good as any standard or system will not go well, because managerial commitment is one of the determinants of the quality of financial statements [28][29]. The results of this study differed from the research who found the management commitment to influence the implementation of accounting standards [27].

\subsubsection{Variable management commitments moderate the influence of internal control system implementation to the quality of financial statements.}

T-statistics result of 0,513 . The result of this calculation is smaller than 1.96 and the path coefficient shows positive values. The results of t-Statistic, so that it can be concluded that the management commitments do not moderate the influence of the variable implementation of internal control system with the quality of financial statements. The interview showed that the leadership had a low commitment. In addition to the less firm leadership style and the inadequate delegation of authority between the higher management to the manager under it raises uncertainty to the staff on duty. The insufficient delegation of authority led to the double task performed by the staff. Another problem that can be excavated is that the frequent policies and regulations change and the accuracy of planning will ultimately make the management commitment low. Planning activities and poor budgets and not mapping the real condition of the field in the end cause the program activities are often not absorbed because it is not on target. This poor planning also causes activities that overlap with budgeting from other funding sources.

\subsubsection{The management commitment variables moderate the influence of accounting standards for the quality of financial statements.}

T-statistics result of 0.010 . The result of this calculation is smaller than 1.96 and the path coefficient shows positive values. The results of t-statistic, so it can be concluded that the management commitment does not moderate the influence of the variable implementation of Accounting standard system with the quality of financial statements. Data shows from 47 samples obtained as much as 17 of them or $37.78 \%$ educated non-accounting. The related human resources interviews also found a turn over staff that is quite often the case. Change of staff who too often pose a separate problem in their job mastery ability while there is insufficient training and technical guidance. This certainly affects the understanding of accounting standards. The interview finds that not all human resource (SDM) understand the concept of accruals in general. This understanding is important considering that transactions are based on accrual bases, as the overall financial activity is tailored to the accrual-based accounting standards. The implementation of accounting standards aims to make the overall financial activity from the budgeting, administration and accountability phases possible in accordance with applicable regulations and standards, so that the relevance of the report Financial statements can be obtained and the resulting financial statements are easy to understand and can be compared. Another thing that is found is the lack of the on time in reporting and the implementation of activities. The implementation of activities that are not well regulated ultimately impact on low funds absorption. Delays in activities are also due to frequent problems of organizational alternated rules. The change of rules that are too often without enough socialization in the end is the fact that the staff confusion in the activities of fear of wrong in management. In the end they prefer not to carry out activities if deemed to be 
inadequate implementation standards. The results of this study differed from the results who found the commitment to moderate the quality of financial statements [30].

\section{Conclusion}

The results found that there was an influence on the implementation of internal control systems on the quality of financial statements, while the implementation of accounting standards did not affect the quality of financial statements. Other findings found that the management's commitment did not moderate the influence of internal control systems implementation and the implementation of accounting standards for the quality of financial statements.

\section{References}

[1] Yusniar, Darwanis, and S. Abdullah, "Pengaruh Penerapan Sistem Akuntansi Pemerintahan dan pengendalian Intern Terhadap Good Governance dan Dampaknya Pada Kualitas Laporan Keuangan (Studi Pada SKPA Pemerintah Aceh)," J. Magister Akunt. Pascasarj. Univ. Syiah Kuala, vol. 5, no. 2, pp. 100-115, 2016.

[2] UU Nomor 15 Tahun, Undang-Undang Republik Indonesia Nomor 15 Tahun 2004 Tentang Pemeriksaan Pengelolaan Dan Tanggung Jawab Keuangan Negara. Indonesia, 2004, pp. 1-25.

[3] D. Suwanda, Wiratmoko, and I. Lindri, Panduan Penerapan "Reviu Laporan Keuangan” Pemerintah Daerah. Bandung: PT Remaja Rosdakarya, 2017.

[4] Suwardjono, Teori Akuntansi (Perekayasaan Pelaporan Keuangan), Edisi Keti. Yogyakarta: BPFE, 2014.

[5] M. Tandiontong, Kualitas Audit dan Pengukurannya, Cetakan ke. Bandung: Alfabeta, CV., 2016.

[6] N. 12 PP, Peraturan Pemerintah Republik Indonesia Nomor 12 Tahun 2019 Tentnag Pengelolaan Keuangan Daerah. Indonesia, 2019.

[7] Harlinda, "Analisis Faktor-faktor yang Mempengaruhi Kualitas Informasi Laporan Keuangan Pemerintah Daerah ( Studi Empiris pada Pemerintah Kabupaten / Kota di Provinsi Riau )," J. Sorot, vol. 11, no. 2, pp. 127-144, 2016.

[8] Margono, Akuntansi Berbasis Akrual Bagi Satuan Kerja Perangkat Daerah. 2015.

[9] Peraturan Pemerintah Nomor 71, Pemerintah Republik Indonesia, Peraturan Pemerintah Nomor 71 Tahun 2010 tentang Standar Akuntansi Pemerintahan. 2010.

[10] F. Van Beest, G. Braam, and S. Boelens, "Quality of Financial Reporting: measuring qualitative characteristics," The Netherlands, 2009.

[11] P. Pemerintah, Nomor 60 Tahun 2008 Tentang Sistem Pengendalian Intern Pemeintah. 2008.

[12] Erviana, "Pengaruh Implementasi Sistem Informasi Manajemen Daerah dan Kegiatan Pengendalian Terhadap Kualitas Laporan Keuangan Pemerintah Daerah (Survey Pada Satuan kerja Perangkat Daerah (SKPD) Kota Palu)," e J. Katalogis, vol. 5, no. 4, pp. 182-193, 2017.

[13] D. P. Kesuma, C. Anwar, and Darmansyah, "Pengaruh Good Governance, Penerapan Standar Akuntansi Pemerintah, Sistem Pengendalian Internal Pemerintah dan Kompentensi Aparatur Pemerintah Terhadap Kualitas Laporan Keuangan Pemerintah Pada Satuan Kerja Kementerian Pariwisata," J. Ilm. WIDYA Ekon., vol. 1, no. 2, pp. 141-146, 2017. 
[14] J. H. Mailoor, J. J. Sondakh, and H. Gamaliel, "Pengaruh Sistem Akuntansi Pemerintahan, Budaya Organisasi, Kinerja Aparatur Pemerintah Daerah, Peran APIP , Dan Sistem Pengendalian Intern Pemerintah Terhadap Penerapan Good Governance ( Studi Empiris Di Kabupaten Kepulauan Talaud )," J. Ris. Akunt. dan Audit. “Goodwill," vol. 8, no. 2, pp. 82-94, 2017.

[15] A. O. Abang'a, "Determinants of quality of financial reporting among semi autonomous government agencies in Kenya," Strathmore University, 2017.

[16] O. F. Onyulo, "Factors Influencing Quality of Financial Reporting in Public Sector Entities in the Ministry of Environment and Natural Resources Kenya," KCA UNIVERSITY, 2017.

[17] D. Suwanda, "Factors Affecting Quality of Local Government Financial Statements to Get Unqualified Opinion (WTP) of Audit Board of the Republic of Indonesia (BPK)," Res. J. Financ. Account., vol. 6, no. 4, pp. 139-157, 2015.

[18] M. W. Abdullah, "Pemoderasi Kompetensi Sumber Daya Manusia Terhadap Peningkatan Kualitas Laporan Keuangan Daerah Kabupaten Bone," J. Ilm. Akunt. Perad., vol. Vol. III, no. No. 2, pp. 45-65, 2010.

[19] Sudarno, "Analisis Peran Karyawan dalam Hubungan Antara Dukungan Pimpinan dengan Efektifitas SPIP dan Kualitas Laporan Keuangan," J. Akunt. dan Audit., vol. 15, no. 1, pp. 115-137, 2018.

[20] B. M. Staw, Motivation in organizations: Toward synthesis and redirection. See Connolly 1 977, 1977.

[21] Syarifudin, N. K. Surasni, and B. A. Inapty, "Determinan Kualitas Laporan Keuangan dan Implikasinya terhadap Akuntabilitas Publik (Studi Empiris pada Inspektorat Kab. Lombok Timur, Kabupaten Bima dan Perwakilan BPKP Provinsi NTB)," in SNA XIX Lampung, 2016.

[22] Silviana, "Pengaruh Komitmen Kepala Daerah Terhadap Kualitas Laporan Keuangan Pemerintah Daerah di Provinsi Jawa Barat," in Seminar NAsional Akuntansi \& Bisnis (SNAB), 2012, pp. 862-869.

[23] I. Ratifah and M. Ridwan, "Komitmen Organisasi Memoderasi Pengaruh Sistem Akuntansi Keuangan Daerah terhadap Kualitas Laporan Keuangan,” Trikonomika, vol. 11, no. 1, pp. 29-39, 2012.

[24] H. N. Tambingon, W. Yadiati, and C. L. Kewo, "Determinant Factors Influencing the Quality of Financial Reporting Local Government in Indonesia," Int. J. Econ. Financ. Issues, vol. 8, no. 2, pp. 262-268, 2018.

[25] A. J. Kibet, "Effects of Management Commitment on Financial Performance of Private Schools : A Survey of Selected Schools in Trans-Nzoia County, Kenya," Eur. J. Bus. Manag., vol. 8, no. 30, pp. 1-5, 2016.

[26] A. Sanjaya, M. Rasuli, and E. Haryani, "Pengaruh Penerapan Standar Akuntansi Pemerintah, Sistem Pengendalian Intern, Sistem Akuntansi Keuangan Daerah, dan Sumber Daya Manusia Terhadap Kualitas Laporan Keuangan Pemerintah Daerah dengan Komitmen Organisasi Sebagai Pemoderasi (Studi Pada SKPD Kabu,” JOM Fekon, vol. 4, no. 1, 2017.

[27] Supriadi, Haliah, and Kartini, "Pengaruh Komitmen Pimpinan terhadap Penerapan Standar Akuntansi Pemerintahan ( Studi pada Pemerintah Kabupaten Jeneponto )," Online Public Acces Perpust. Univ. Hasanuddin, no. 2, 2018.

[28] A. S. Purwati, "Faktor-Faktor Yang Mempengaruhi Kualitas Laporan Keuangan Pada UMKM di Kabupaten Banyumas,” J. Proceeding JPFBUNSOED, pp. 808-818, 2016.

[29] H. Usman, Manajemen (Teori, Praktek, dan Riset Pendidikan). Jakarta: Bumi Aksara, 
2010.

[30] I. Ratifah and M. Ridwan, "Komitmen Organisasi Memoderasi Pengaruh Sistem Akuntansi Keuangan terhadap Kualitas Laporan Keuangan," Trikonomika, vol. 11, no. 1, pp. 29-39, 2012. 